\title{
PERANCANGAN SISTEM INFORMASI PROMOSI TOUR WISATA DAN PEMESANAN PAKET TOUR WISATA DAERAH KERINCI JAMBI PADA CV. RINAI BERBASIS OPEN SOURCE
}

\author{
Nico Alvio Maiyedra \\ email: nicoalvio34@gmail.com \\ Program Studi Sistem Informasi, STMIK GICI
}

\begin{abstract}
Abstrak
Salah satu hasil dari kemajuan teknologi informasi adalah dengan adanya pembuatan epromosi dan pemesanan yang digunakan sebagai media promosi, pemesanan, grafik informasi dan banyak hal lain yang dapat di manfaatkan. E-promosi dan pemesanan merupakan bagian dari suatu situs web yang memungkinkan pengguna untuk mengetahui grafik informasi seputar tentang lokasi wisata, harga paket wisata dan kebutuhan lainnya. Secara umum e-promosi dan pemesanan memungkinkan webmaster untuk mendefenisikan tema seputar tentang wisata kerinci. Pengguna yang lain dapat mengetahui informasi lokasi wisata dan juga dapat memesan secara langsung ke sistem, CV. RINAI di daerah kerinci adalah salah satu usaha yang bergerak didalam jasa angkutan mobil dimana pada CV. RINAI menerapkan jasa Antar jemput, Paket Wisata dan lain sebagainya seputar tentang wisata kerinci. karena itu di butuhkan E-promosi dan Pemesanan yang menyajikan wadah grsfik informasi sehingga wisatawan yang ingin mengetahui seputar informasi Lokasi Wisata, Paket Wisata dan lain sebegainya.
\end{abstract}

\section{Abstract}

One result of the advancement of information technology is the creation of epromotion and ordering that is used as a media promotion, ordering, graphics information and many other things that can be utilized. E-promotions and bookings are part of a website that allows users to know the information graph about the location of the tour, the price of the tour package and other needs. In general e-promotions and bookings allow webmasters to define themes around the rabbit tour. Other users can find tourist location information and can also order directly to the system, CV. RINAI in Kerinci area is one of the business that is engaged in car transport services where the CV. RINAI apply the shuttle service, Tour Package and so forth about about kerinci tou. Because it is needed E-Promotion and Booking that presents a container grsfik information so that tourists who want to know about the Tourist Location Information, Tour Packages and others sebegainya

Keywords : technology, information systems, promotion tourism location and reservation tourism.

\section{PENDAHULUAN}

Pemanfaatan komputer dalam

kehidupan masyarakat semakin

berkembang. Jika dulu orang memanfaatkan komputer sebatas alat pengolah data, maka sekarang dengan menggunakan komputer dan didukung oleh kecanggihan teknologi maka komputer 
Volume 7 No. 1

memungkinkan sebagai alat penyebar informasi di kalangan masyarakat. Informasi-informasi terkini dapat di sebarluaskan tidak terbatas ruang dan waktu. Salah satu hasil dari kemajuan teknologi informasi adalah dengan adanya pembuatan e-promosi dan pemesanan yang digunakan sebagai media promosi, pemesanan, grafik informasi dan banyak hal lain yang dapat di manfaatkan. E-promosi dan pemesanan merupakan bagian dari suatu situs web yang memungkinkan pengguna untuk mengetahui grafik informasi seputar tentang lokasi wisata, harga paket wisata dan kebutuhan lainnya. Secara umum epromosi dan pemesanan memungkinkan webmaster untuk mendefenisikan tema seputar tentang wisata kerinci. Pengguna yang lain dapat mengetahui informasi lokasi wisata dan juga dapat memesan secara langsung ke sistem. CV. RINAI di daerah kerinci adalah salah satu usaha yang bergerak didalam jasa angkutan mobil dimana pada CV. RINAI menerapkan jasa Antar jemput, Paket Wisata dan lain sebagainya seputar tentang wisata kerinci.

\section{TUJUAN PENELITIAN}

Adapun tujuan dari penelitian ini adalah untuk membangun sebuah web informasi dan promosi dengan menggunakan bahasa pemograman PHP. Hal tersebut penulis harapkan dapat berguna bagi banyak pihak dalam memperoleh informasi dan juga penerapan ilmu dari apa yang penulis dapatkan di bangku kuliah.

\section{LANDASAN TEORI}

Dalam pengambilan keputusan sangat diperlukan informasi yang tepat dan akurat. Informasi yang dihasilkan hendaknya sesuai dengan kebutuhan. Dimana informasi itu diperoleh melalui sistem yang dibuat dengan sistem informasi.

\section{Alat Bantu Dalam Merancang Sistem UML (Unified Modeling Language) \\ 1. Use case Diagram Use case diagram adalah deskripsi fungsi dari sebuah sistem dari perspektif penggguna. Use case diagram bekerja dengan cara mendeskripsikan tipikal interaksi antara user sebuah sistem dengan sistemnya sendiri melaluhi sebuah cerita bagaimana sebuah sistem dipakai.Dapat dilihat pada Tabel 1.}

Tabel 1. Simbol Use Case Diagram

\begin{tabular}{|c|c|c|c|}
\hline NO & GAMBAR & NAMA & KETERANGAN \\
\hline 1 & 9 & Actor & $\begin{array}{l}\text { Menspesifikasikan } \\
\text { himpuan peran } \\
\text { yang pengguna } \\
\text { mainkan ketika } \\
\text { berinteraksi } \\
\text { dengan use case. }\end{array}$ \\
\hline 2 & $\cdots$ & $\begin{array}{l}\text { Dependenc } \\
y\end{array}$ & $\begin{array}{l}\text { Hubungan dimana } \\
\text { perubahan yang } \\
\text { terjadi pada suatu } \\
\text { elemen mandiri } \\
\text { (independent) } \\
\text { akan } \\
\text { mempengaruhi } \\
\text { elemen yang } \\
\text { bergantung } \\
\text { padanya elemen } \\
\text { yang tidak } \\
\text { mandiri } \\
\text { (independent). }\end{array}$ \\
\hline 3 & $\leftarrow$ & $\begin{array}{l}\text { Generalizat } \\
\text { ion }\end{array}$ & $\begin{array}{l}\text { Hubungan dimana } \\
\text { objek anak } \\
\text { (descendent) } \\
\text { berbagi perilaku } \\
\text { dan struktur data } \\
\text { dari objek yang } \\
\text { ada di atasnya } \\
\text { objek induk } \\
\text { (ancestor). } \\
\end{array}$ \\
\hline 4 & $-\cdots--->$ & Include & $\begin{array}{l}\text { Menspesifikasikan } \\
\text { bahwa use case } \\
\text { sumber secara } \\
\text { eksplisit. }\end{array}$ \\
\hline
\end{tabular}


Volume 7 No. 1

\begin{tabular}{|c|c|c|c|}
\hline 5 & $\triangleleft$ & Extend & $\begin{array}{l}\text { Menspesifikasikan } \\
\text { bahwa use case } \\
\text { target memperluas } \\
\text { perilaku dari use } \\
\text { case sumber pada } \\
\text { suatu titik yang } \\
\text { diberikan. }\end{array}$ \\
\hline 6 & & Association & $\begin{array}{l}\text { Apa yang } \\
\text { menghubungkan } \\
\text { antara objek satu } \\
\text { dengan objek } \\
\text { lainnya. }\end{array}$ \\
\hline 7 & & System & $\begin{array}{l}\text { Menspesifikasikan } \\
\text { paket yang } \\
\text { menampilkan } \\
\text { sistem secara } \\
\text { terbatas. }\end{array}$ \\
\hline 8 & & Use Case & $\begin{array}{l}\text { Deskripsi dari } \\
\text { urutan aksi-aksi } \\
\text { yang ditampilkan } \\
\text { sistem yang } \\
\text { menghasilkan } \\
\text { suatu hasil yang } \\
\text { terukur bagi suatu } \\
\text { actor }\end{array}$ \\
\hline 9 & & $\begin{array}{l}\text { Collaborati } \\
\text { on }\end{array}$ & $\begin{array}{l}\text { Interaksi aturan- } \\
\text { aturan dan elemen } \\
\text { lain yang bekerja } \\
\text { sama untuk } \\
\text { menyediakan } \\
\text { prilaku yang lebih } \\
\text { besar dari jumlah } \\
\text { dan elemen- } \\
\text { elemennya } \\
\text { (sinergi). }\end{array}$ \\
\hline 10 & & Note & $\begin{array}{l}\text { Elemen fisik yang } \\
\text { eksis saat aplikasi } \\
\text { dijalankan dan } \\
\text { mencerminkan } \\
\text { suatu sumber daya } \\
\text { komputasi }\end{array}$ \\
\hline
\end{tabular}

Sumber : Buku Rekayasa Perangkat Lunak karangan Rosa A.S, M Shalahuddin, 2011

\section{Class Diagram}

Class adalah deskripsi kelompok obyek-obyek dengan properti, perilaku dan relasi yang sama. Sehingga dengan adanya class diagram dapat memberikan pandangan global atas sebuah sistem. Hal tersebut tercermin dari class-class yang ada dan relasinya satu dengan yang lainnya. Sebuah sistem biasanya mempunyai beberapa class diagram. Dapat dilihat pada Tabel 2.

Tabel 2. Simbol Class Diagram

\begin{tabular}{|c|c|c|c|}
\hline NO & GAMBAR & NAMA & KETERANGAN \\
\hline 1 & & Generalization & $\begin{array}{l}\text { Hubungan dimana } \\
\text { objek anak } \\
\text { (descendent) } \\
\text { berbagi perilaku } \\
\text { dan struktur data } \\
\text { dari objek yang } \\
\text { ada di atasnya } \\
\text { objek induk } \\
\text { (ancestor). }\end{array}$ \\
\hline 2 & & $\begin{array}{l}\text { Nary } \\
\text { Association }\end{array}$ & $\begin{array}{l}\text { Upaya untuk } \\
\text { menghindari } \\
\text { asosiasi dengan } \\
\text { lebih dari } 2 \text { objek. }\end{array}$ \\
\hline 3 & & Class & $\begin{array}{l}\text { Himpunan dari } \\
\text { objek-objek yang } \\
\text { berbagi atribut } \\
\text { serta operasi yang } \\
\text { sama. }\end{array}$ \\
\hline 4 & & Collaboration & $\begin{array}{l}\text { Deskripsi dari } \\
\text { urutan aksi-aksi } \\
\text { yang ditampilkan } \\
\text { sistem yang } \\
\text { menghasilkan } \\
\text { suatu hasil yang } \\
\text { terukur bagi suatu } \\
\text { actor } \\
\end{array}$ \\
\hline 5 & $\triangleleft-\cdots--$ & Realization & $\begin{array}{l}\text { Operasi yang } \\
\text { benar-benar } \\
\text { dilakukan oleh } \\
\text { suatu objek. }\end{array}$ \\
\hline 6 & $\cdots-\cdots$ & Dependency & $\begin{array}{l}\text { Hubungan dimana } \\
\text { perubahan yang } \\
\text { terjadi pada suatu } \\
\text { elemen mandiri } \\
\text { (independent) } \\
\text { akan mempegaruhi } \\
\text { elemen yang } \\
\text { bergantung } \\
\text { padanya elemen } \\
\text { yang tidak mandiri }\end{array}$ \\
\hline 7 & & Association & $\begin{array}{l}\text { Apa yang } \\
\text { menghubungkan } \\
\text { antara objek satu } \\
\text { dengan objek } \\
\text { lainnya }\end{array}$ \\
\hline
\end{tabular}

Sumber : Buku Rekayasa Perangkat Lunak karangan Rosa A.S, M Shalahuddin, 2011

\section{Sequence Diagram}

Sequence diagram menggambarkan interaksi antar objek di dalam dan di sekitar sistem (termasuk pengguna, display, dan sebagainya) berupa message yang digambarkan terhadap waktu. Dapat dilhat pada Tabel 3.

Tabel 3. Simbol Sequence Diagram 
Volume 7 No. 1

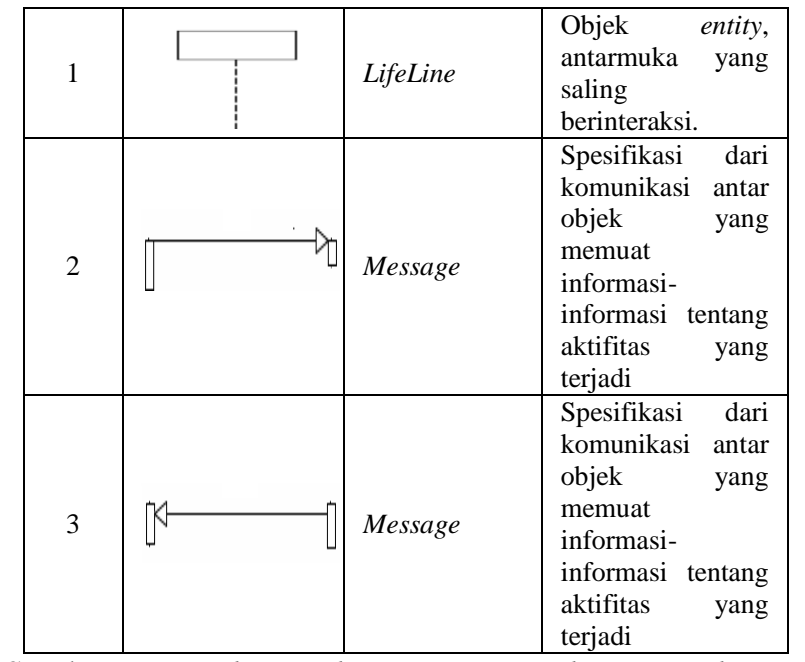

Sumber : Buku Rekayasa Perangkat Lunak karangan Rosa A.S, M Shalahuddin, 2011

\section{Diagram aktifitas}

Activity diagram adalah teknik untuk mendiskrispikan logika prosedural, proses bisnis dan aliran kerja dalam banyak kasus. Dapat dilihat pada Tabel 4.

Tabel 4. Simbol Activity Diagram

\begin{tabular}{|c|c|l|l|}
\hline NO & GAMBAR & NAMA & \multicolumn{1}{|c|}{ KETERANGAN } \\
\hline 1 & & $\begin{array}{l}\text { Memperlihatkan } \\
\text { bagaimana masing- } \\
\text { masing kelas } \\
\text { antarmuka saling } \\
\text { berinteraksi satu sama } \\
\text { lain }\end{array}$ \\
\hline 2 & & Action & $\begin{array}{l}\text { State dari sistem yang } \\
\text { mencerminkan } \\
\text { eksekusi dari suatu } \\
\text { aksi }\end{array}$ \\
\hline 3 & & $\begin{array}{l}\text { Initial } \\
\text { Node }\end{array}$ & $\begin{array}{l}\text { Bagaimana objek } \\
\text { dibentuk atau diawali. }\end{array}$ \\
\hline 4 & $\bigcirc$ & $\begin{array}{l}\text { Actifity } \\
\text { Final } \\
\text { Node }\end{array}$ & $\begin{array}{l}\text { Bagaimana objek } \\
\text { dibentuk dan } \\
\text { dihancurkan }\end{array}$ \\
\hline
\end{tabular}



Sumber : (MADCOMS, 2008.Teknik Mudah Menbangun Website Dengan PHP)

\section{Deployment Diagram}

Deployment diagram menunjukkan tata letak sebuah sistem secara fisik, menampakkan bagian-bagian software yang berjalan pada bagian hardware. Dapat dilihat pada Tabel 5.

Tabel 5. Simbol Deployment Diagram

\begin{tabular}{|c|c|l|l|}
\hline $\begin{array}{l}\mathrm{N} \\
\mathrm{O}\end{array}$ & GAMBAR & NAMA & $\begin{array}{l}\text { KETERANGA } \\
\mathrm{N}\end{array}$ \\
\hline 1 & & $\begin{array}{l}\text { Kompone } \\
\mathrm{n}\end{array}$ & $\begin{array}{l}\text { node adalah } \\
\text { sumber daya } \\
\text { fisik yang } \\
\text { menjalankan } \\
\text { kode } \\
\text { komponen. }\end{array}$ \\
\hline 2 & Node Name & $\begin{array}{l}\text { Asosiasi } \\
\text { mengacu pada } \\
\text { koneksi fisik } \\
\text { antara node, } \\
\text { seperti Ethernet. }\end{array}$ \\
\hline 3 & Asosiasi & $\begin{array}{l}\text { komponen di } \\
\text { dalam node } \\
\text { yang } \\
\text { menyebarkan } \\
\text { mereka. }\end{array}$ \\
\hline Korver & $\begin{array}{l}\text { Noded } \\
\text { Nodes }\end{array}$ & \\
\hline
\end{tabular}

Sumber : Buku Rekayasa Perangkat Lunak karangan Rosa A.S, M Shalahuddin, 2011

\section{Konsep Dasar Pemrograman}

PHP Dan database MySQL merupakan suatu bentuk produk dari open source, yang gratis yang dapat digunakan siapapun tanpa ada membayar lisensi dari produk tersebut. Pada bagian ini akan dibahas tentang konsep dasar pemrograman PHP dan MySQL untuk mendukung aplikasi yang dibuat.

\section{HASIL DAN PEMBAHASAN Analisa Sistem}

Analisis Sistem adalah penguraian dari suatu sistem informasi yang utuh kedalam 
Volume 7 No. 1

Mei 2019

bagian-bagian komponennya dengan maksud untuk mengidentifikasi dan mengevaluasi permasalahan, kesempatan, dan hambatan-hambatan yang mungkin terjadi serta kebutuhan yang diharapkan sehingga dapat diusulkan perbaikan. Tujuan analisa sistem adalah agar dapat ditemukan sistem yang tepat. Minim kesalahan, mudah digunakan dan diharapkan dapat menentukan alur rancangan sistem yang tepat dalam perancangan sistem informasi promosi tour wisata dan pemesanan paket wisata daerah kerinci.

\section{Diagram Unified Modeling Language (UML)}

\section{Diagram Use Case}

Diagram use case merupakan jenis diagram perilaku yang didefenisikan oleh dan diciptakan dari analisa kasus. Tujuannya adalah untuk menyajikan gambaran grafis dari fungsionalitas yang disediakan oleh sistem dalam hal pelaku, tujuan mereka (direpresentasikan sebagai kasus penggunaan), dan setiap ketergantungan antara kasus-kasus digunakan.

\section{Diagram Use Case Yang Sedang Berjalan}

Gambaran dibawah ini merupakan diagram use case yang sedang berjalan, dimana aktor mengelola beberapa sistem yang akan ditampilkan. Dapat dilihat pada Gambar 1

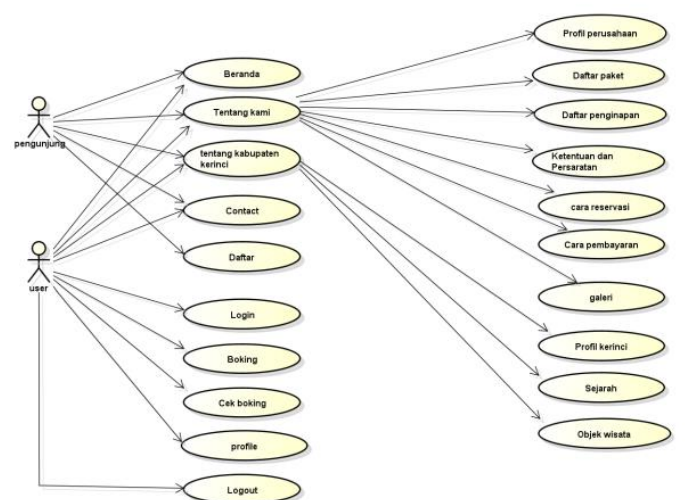

Gambar 1. Diagram Use Case pengumjung dan user

\section{Diagram Use Case Untuk Admin}

Gambar dibawah ini merupakan diagram use case untuk admin, dimana admin mengelola beberapa sistem yang akan ditampilkan. Dapat dilihat pada Gambar 2.

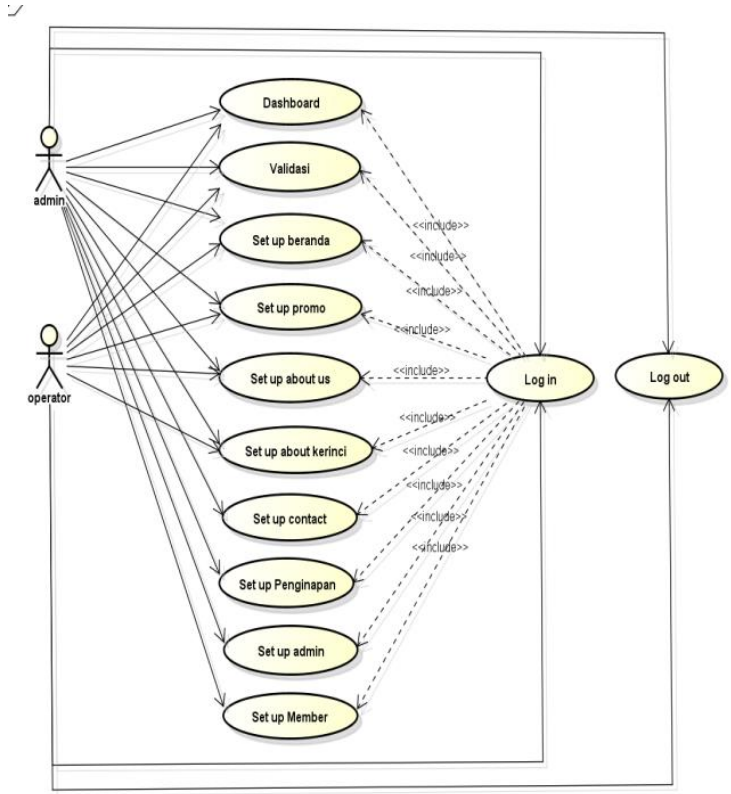

Gambar 2 Diagram Use Case Untuk Admin dan operator

\section{Diagram Kelas}

Class merupakan sebuah spesifikasi yang akan menghasilkan sebuah objek dan merupakan inti dari pengembangan dan desain berorientasi objek. Class menggambarkan keadaan (atribut/properti) 
suatu sistem, sekaligus menawarkan layanan untuk memanipulasi keadaan tersebut. Seperti pada Gambar 3.



Gambar 3. Class Diagram Pada Website Toko Summerch

\section{Diagram Sequence}

Diagram sequence digunakan untuk mengambarkan perilaku pada sebuah skenario. Kegunaannya untuk menunjukan rangkaian pesan yang dikirm antara object juga interaksi antara object, sesuatu yang terjadi pada titik tertentu dalam eksekusi sistem.

\section{Diagram Sequence admin}

Diagram ini menjelaskan urutan langkah-langkah yang dapat dilakukan oleh admin kedalam sistem. Dapat dilihat pada Gambar 4.



Gambar 4. Sequence Diagram Admin

\section{Diagram Sequence operator}

Diagram ini menjelaskan urutan langkah-langkah yang dapat dilakukan oleh operator di dalam sistem. Dapat dilihat pada Gambar 5.



Gambar 5. Sequence Diagram operator

\section{Diagram Sequence User}

Diagram ini menjelaskan urutan langkah-langkah yang dapat dilakukan oleh user kedalam sistem. Dapat dilihat pada Gambar 6. 




Gambar 6. Sequence Diagram Untuk Tambah Produk

\section{Pengujian Sistem}

Pengujian terhadap system dilakukan untuk mengetahui sejauh mana system informasi yang dirancang dapat mengatasi masalah, serta untuk mengetahui hubungan antar komponen sistem. Dengan demikian langkahlangkahnya sebagai berikut :

\section{Layout Beranda}

Layout Beranda adalah halaman yang pertama kali muncul saat alamat situs diakses. Pada halaman depan terdapat menu utama yang tersedia yaitu: Beranda, Tentang kami, Tentang Kerinci, contact dan login. Gambar layout menu utama dapat dilihat seperti pada gambar 4.10


Gambar 10. Layout Halaman Beranda

1. Layout Layout Tentang kami
Layout Tentang kami Tersedia beberapa menu yaitu: Profile, Daftar Paket, Ketentuan dan persyaratan, cara reservasi, dan Cara Pembayaran. dapat di lihat pada gambar 4.11


\section{Gambar 4.11 Tentang kami}

2. Layout Tentang Kerinci

Layout Tentang kami Tersedia menu yaitu: Profil, Sejarah, Galeri, dan Objek wisata.yang dapat di lihat pada gambar 4.13



\section{Gambar 4.13 Layout Call Us}

3. Layout Contact

Layout Contact berisikan data alamat dan kontak yg bisa di hubungi. dapat di lihat pada gambar 4.14 
ISSN $2338-1523$

E-ISSN $2541-576$ X

Volume 7 No. 1

Mei 2019

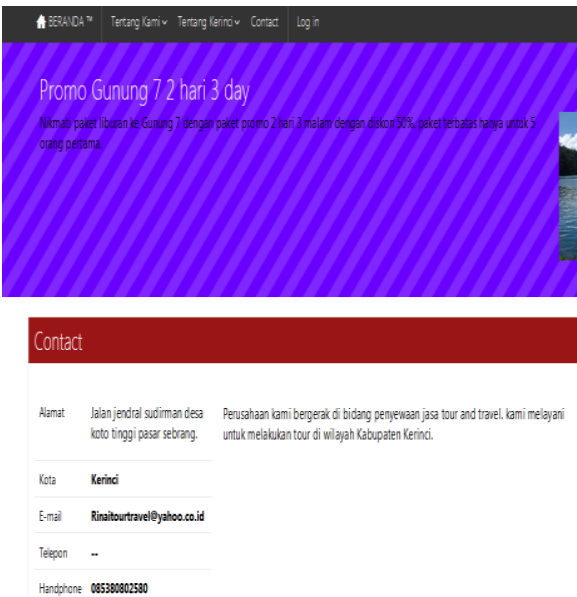

\section{Gambar 4.14 Layout Contact}

4. Layout Login

Layout Login terdapat menu login dan sigup, user melakukan pendaftaran dan melakukan login. dapat di lihat padagambar 4.154 .16



Silahkan regirter di form berikut!

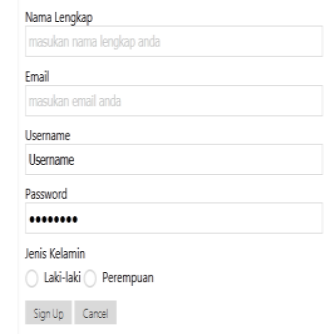

Gambar 4.15 Layout sigup
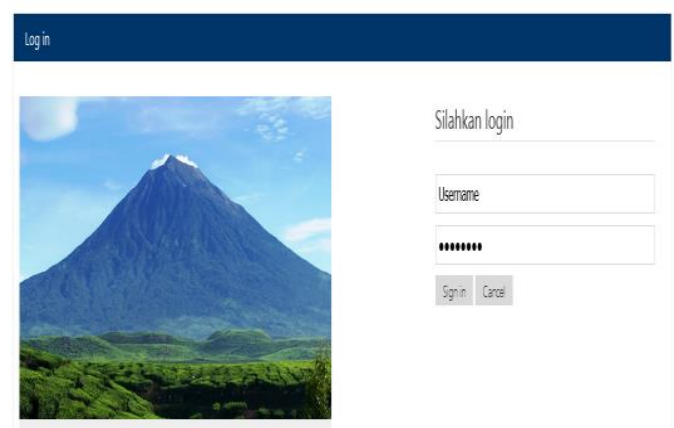

Silahkan login

Usemame

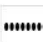

Sgin core

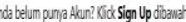

Gambar 4.16 Layout Login

5. Layout Pofil

Layout Profil berisikan data user dapat di lihat pada gambar 4.17

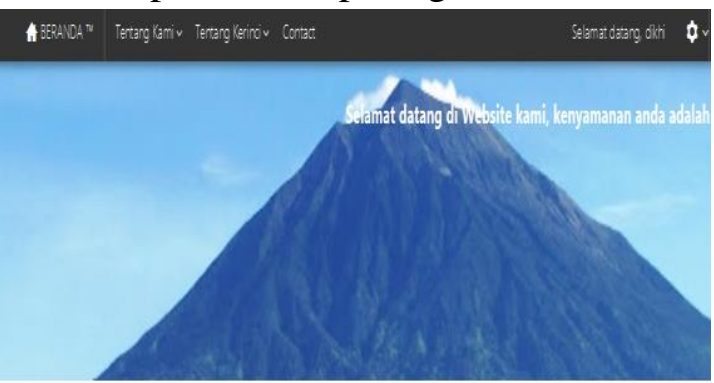

dikhiarizal

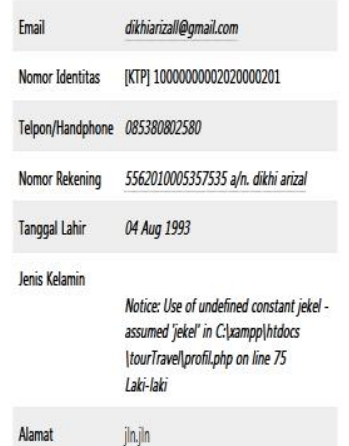

Gambar 4.17 Layout Profil

6. Layout Booking

Layout Booking berisikan data file dapat di lihat pada gambar 4.18 
ISSN $2338-1523$

E-ISSN $2541-576$ X

Volume 7 No. 1

Mei 2019

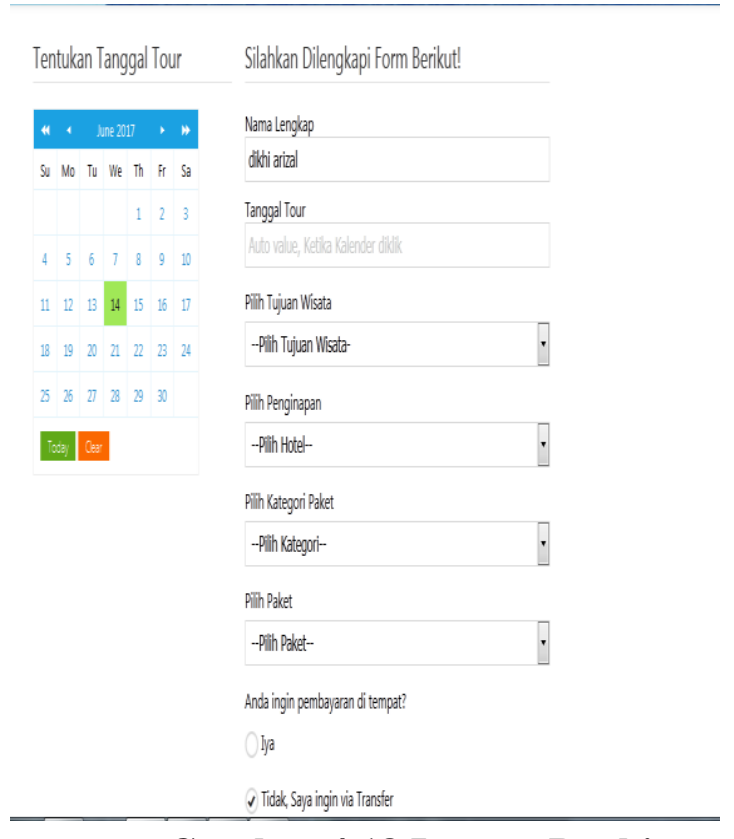

Gambar 4.18 Layout Booking

7. Layout Cek boking

Layout Cek Booking berisikan data pemesanan paket, dan mencetak tiket apabila telah di proses oleh admin dapat di lihat pada gambar 4.18

\begin{tabular}{|c|c|c|c|c|c|c|c|c|}
\hline D prean & $\begin{array}{l}\text { Tangal } \\
\text { Pearan }\end{array}$ & $\begin{array}{l}\text { Tanggal } \\
\text { Tour }\end{array}$ & Paket Tour & Tempat Pengingan & $\begin{array}{l}\text { Harge } \\
\text { Paket }\end{array}$ & $\begin{array}{l}\text { Herges } \\
\text { Penginapan }\end{array}$ & $\begin{array}{l}\text { Herge } \\
\text { Total }\end{array}$ & Alsi \\
\hline RNA-NOS & $2017-6 \cdot 12$ & $2017-66-13$ & $\begin{array}{l}\text { Gunvag Keino } \\
\text { 3-day }\end{array}$ & 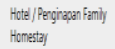 & $120000 \mathrm{DP}$ & $200000 \mathrm{DR}$ & $\begin{array}{l}1400000 \\
\mathbb{D} R\end{array}$ & Gathesel \\
\hline RNA-010 & o $2017 \cdot 6 \cdot 6-13$ & $2017-66-15$ & $\begin{array}{l}\text { Gunruglemino } \\
\text { 3-day }\end{array}$ & 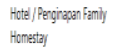 & $1200000 \mathrm{dz}$ & 20000 DR & $\begin{array}{l}1400000 \\
\mathbb{D} R\end{array}$ & costhe \\
\hline RDM:0.012 & $2017-\sqrt[6]{6-14}$ & $2017-66-15$ & $\begin{array}{l}\text { Gunvalkenino } \\
\text { 3-dey }\end{array}$ & $\begin{array}{l}\text { Hotel Pergirapan Finily } \\
\text { Honstatej }\end{array}$ & $1200000 \mathrm{DP}$ & $200000 \mathrm{DR}$ & $\begin{array}{l}1400000 \\
D R\end{array}$ & $\begin{array}{l}\text { Merungy } \\
\text { Luboso } \\
\text { But }\end{array}$ \\
\hline
\end{tabular}

\section{Gambar 4.18 Layout cek booking}

8. Layout Upload bukti pembayaran

Pada layout ini user mengupload bukti pembayaran. dapat dilihat pada gambar 4.19

\section{Upload Bukti Pembayaran \\ Upload buici bahwa anda telah melakikan

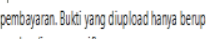 \\ gambar (jpg, ppo, gitf. \\ Telssil... Tiddak ada berkas ípith}

Gambar 4.23 Layout Upload Bukti Pembayaran

9. Layout Cetak Tiket

Pada layout ini merupakan proses pembayaran telah di acc oleh admin dan tiket bisa di cetak atau di download. dapat dilihat pada gambar 4.23

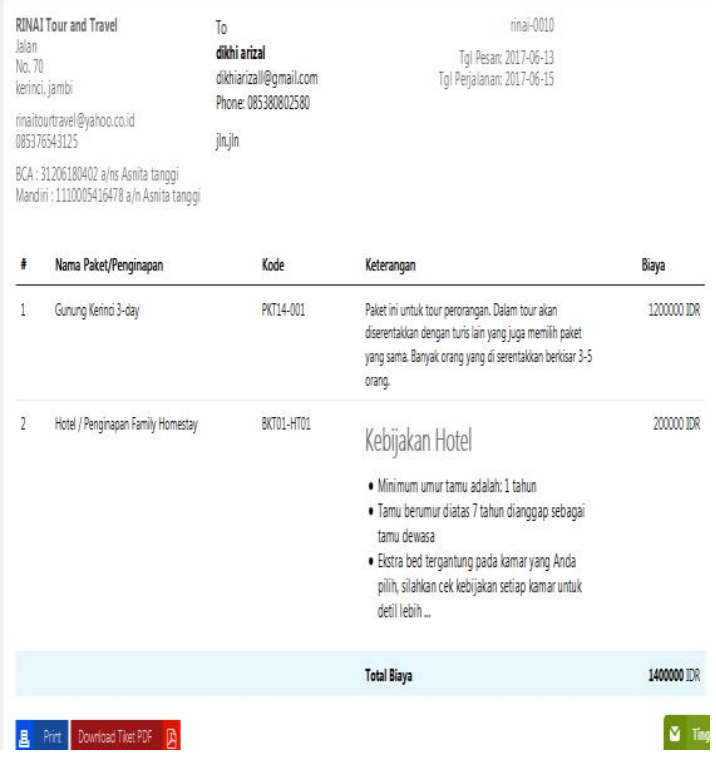

Gambar 4.19 Layout Cetak Tiket

10. Layout Login Admin

Layout Login Admin dapat di lihat pada gambar 4.20 
ISSN $2338-1523$

E-ISSN $2541-576$ X

Volume 7 No. 1

Mei 2019

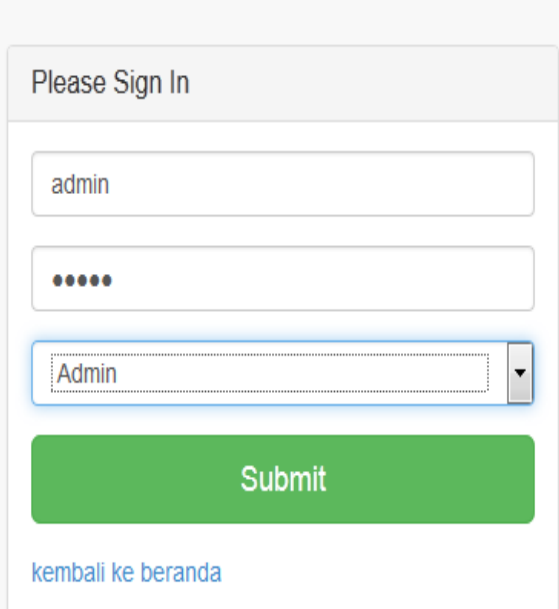

Gambar 4.20 Layout Upload

11. Layout Dashboard Admin

Pada Layout ini Admin melihat transaksi terbaru yang di lakukan oleh user. Dapat di lihat pada gambar 4.21

\begin{tabular}{lllll} 
【ili Transaksi Terkini & & & \\
ID & Tgl Pesan & Tgl Tour & Nama Pelanggan & Status \\
\hline 12 & $2017-06-14$ & $2017-06-15$ & dikhi arizal & Menunggu \\
\hline 10 & $2017-06-13$ & $2017-06-15$ & dikhi arizal & Lunas \\
\hline 9 & $2017-06-12$ & $\mathbf{A} 2017-06-13$ & dikhi arizal & Lunas
\end{tabular}

\begin{tabular}{llll} 
Gil Bukti Pembayaran yang Ter-Upload Terkini & \\
$\#$ & ID Pesan & Nama & File \\
\hline 1 & 9 & dikhi arizal & Lihat File \\
\hline 2 & 10 & dikhi arizal & Lihat File \\
\hline 3 & 12 & dikhi arizal & Lihat File \\
\hline 4 & 12 & dikhi arizal & Lihat File
\end{tabular}

\section{Gambar 4.21 Layout Forum Guru}

12. Layout Validasi
Layout
Validasi
Admin mengkonfirmasi status pembayaran. dapat di lihat pada gambar 4.22

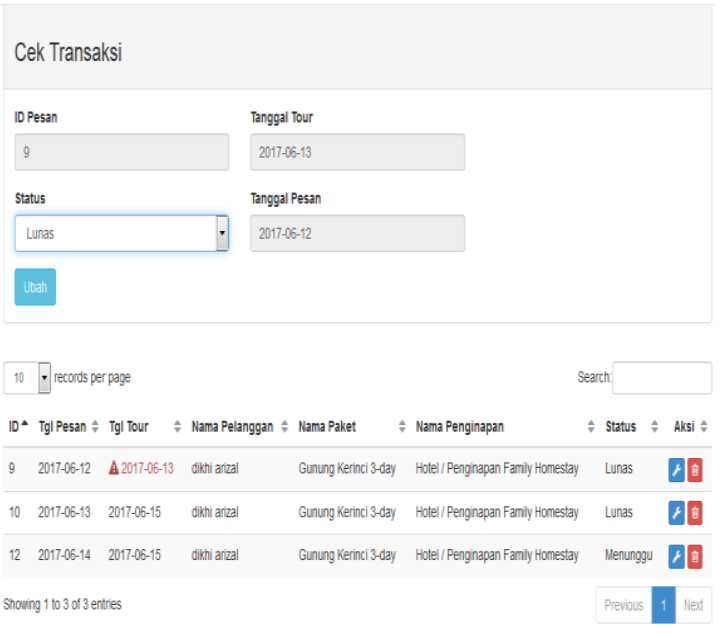

Gambar 4.22 Layout Profil Siswa

13. Layout Setup Member

Layout Setup Member admin dapat mengedit dan menghapus data user. oleh siswa dapat di lihat pada gambar 4.37,

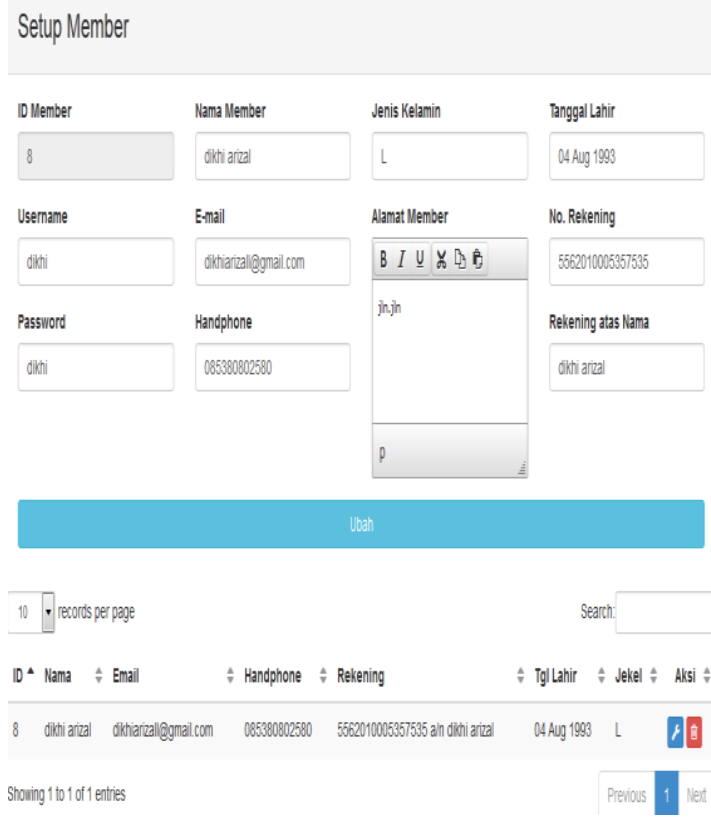

Gambar 4.37 Layout Setup data user

\section{KESIMPULAN}


Demikianlah penjelasan dari pembuatan website pada CV Rinai. Dari analisis dan pembahasan yang telah dilakukan, maka dapat diambil beberapa kesimpulan sebagai berikut:

1. Dengan adanya website maka CV Rinai dapat memperkenalkan atau mempromosikan lokasi wisata terbaru kepada masyarakat luas.

2. Website ini akan mempermudah pelanggan yang ingin memesan paket wisata lengkap dengan informasiinformasi lokasi wisata.

3. Tujuan lain dirancangnya website ini adalah untuk dapat menarik konsumen dalam melakukan pemesanan kapanpun dan di mana pun karna dapat diakses dimanapun, sehingga dapat meningkatkan jumlah penjualan pada CV Rinai.

\section{Saran}

Dengan adanya sistem yang sedang berjalan maupun sistem yang sedang dikembangkan, maka disarankan :

1. Website CV Rinai yang dirancang ini sebaiknya lebih mengembangkan sistem keamanan, guna menanggulangi kerusakan sistem serta kejahatan dunia maya (hacker) yang setiap waktu mengancam.

2. Dilakukan peninjauan ulang terhadap sistem yang baru dan jika ada kekurangan ataupun kelemahan dari sistem yang baru ini maka dilakukan perbaikan.

3. Informasi-informasi produk jasa dan lokasi wisata sebaiknya lebih terinci dengan keterangan dari tiap-tiap

JURSIMA https://ejournal.giciku.ac.id/

tampilan seperti ada nya produk terbaru lengkap dengan keterangan langsung tentang produk, sehingga pelanggan tidak bingung saat mencari produk yang mereka inginkan.

\section{KATA TERIMAKASIH}

Trimakasih kepada teman-teman yang telah mensuport saya, dan tidak lupa saya trimakasih kepada allah atas segala rahmat dan karunia yang telah di berikan kepada saya, dan trimakasih kepada kepada orang tua saya ucapkan karna telah mendidik saya dari lahir hingga saat ini.

\section{DAFTAR REFERENSI}

Ardhana.YM Kusuma. Tahun 2014. Project Php dan MySQL Membuat Website Buku Digital. Purwokerto : Jasakom.

A.S ROSA dan M.Shalahuddin. Tahun 2011. Rekayasa Perangkat Lunak. Bandung: Informatika.

Hidayatullah Priyanto dan Januari Khairul Kawistan. Tahun 2014. Bandung: Informatika.

Pratama, Putu Agus Eka. 2014. Sistem Informasi dan Implementasinya. Bandung :INFORMATIKA

http://statistikdasar.com/files/materi/p enyajian_data_dalam_diagram.pdf 